\title{
Zinc Finger Protein PLAG1
}

National Cancer Institute

\section{Source}

National Cancer Institute. Zinc Finger Protein PLAG1. NCI Thesaurus. Code C71447.

Zinc finger protein PLAG1 (500 aa, 56 kDa) is encoded by the human PLAG1 gene. This protein is a $\mathrm{C} 2 \mathrm{H} 2$-type zinc finger transcription factor that regulates the expression of genes involved in the induction of cellular proliferation. 